\title{
Economic and Geoecological Losses from the Development of Nickel Deposits in the Central Black Soil Region of Russia
}

\author{
Medovar Yu A* and Yushmanov IO \\ Water Problems Institute, Russian Academy of Sciences, Moscow, Russia \\ Submission: February 15, 2019; Published: May 29, 2019 \\ *Corresponding author: Medovar Yu A. Water Problems Institute, Russian Academy of Sciences, Moscow, Gubkina str. 3, Russia
}

\begin{abstract}
The planned production of copper-nickel ore in the Central black earth zone of Russia (Voronezh region) at the current level of environmental measures will lead to irreparable environmental consequences. The negative impact of the mining and processing plant on the environment, groundwater, air, soil is shown. Economic losses due to irreplaceable damage on fertile soils are estimated.
\end{abstract}

Keywords: Copper-nickel deposits; Ore enrichment, ecology; Groundwater; Black soil; Khoper river; Acid rain; Economic losses

\section{Introduction}

In 2012, it was decided to develop the Yelansky and Yelkinsky copper-nickel deposits in the Novokhopersky District of the Voronezh Region. It is planned to build a mining and processing plant, with a full mining and smelting cycle in a densely populated area with unique black-earth soils. This can lead to irreversible environmental losses in the most productive agricultural region of Russia - the black earth zone.

What are the dangers of mining nickel ores?

a. The development of the deposit will be carried out by the mining method, therefore, there will be a huge amount of overburden and spent rock, which will then be placed in tailing sites directly on black soil.

b. At the stage of ore processing - during flotation when the reagents are used - silicon and aluminosilicates (spars) are removed, at a cost of about 50 cubic meters of water per ton of ore concentrate (and the design capacity of the enterprise is about one million tons of refined ore per year). For a closed water circulation, expensive treatment facilities are necessary, and there are no guarantees that they will be put into operation.

a. The next stage is the primary firing. The resulting smoke contains sulfuric acid.

Voronezh region is located in the central part of Russia. The winds in the steppes will spread polluted emissions over thousands of kilometers. It will be impossible to use groundwater at all. During drilling, several aquifers will be passed. Changeover of aquifers dehydrates a large area. The redistribution of water resources in the area will disrupt the ecosystem consisting of wet forests, rivers, lakes and swamps, which will lead to an ecological catastrophe. Disputes around the project concern several areas at once: ecology, economics and even politics.

\section{Water}

Groundwater in the zone of slow water exchange in the form of concentrated brines can reach the surface due to redistribution of reservoir pressure and lead to catastrophic salinization of black soil.

There may be problems with the water supply of the local population in the region. The development of the copper-nickel deposit will decrease the flow not only in the river Khoper, but also in the river Don.

Within the area of distribution of cones of depression, and this area is approximately $5000 \mathrm{~km} 2$, we should expect the emergence of negative phenomena for the entire ecosystem. Reducing the level of groundwater will increase the capacity of the aeration zone, which will cause intensive oxidation of soil organic substances and thereby reduce their fertility. As a result, lowering the level of groundwater will lead to disruption of the connection between surface and ground waters, and significant costs of natural water for the development of the field can lead to the complete destruction of local water bodies, reducing the water content of rivers. 
The total water inflow from aquifers to the mine can be $3000 \mathrm{~m} 3$ /day [1]. Concentrated brines are deposited over the ore bodies. The yield of these brines (with mineralization of 70 $\mathrm{g} /$ liter) with a high content of bromine and iodine on the surface will lead to a complete loss of black soils. The limit of possible use of water resources of the river for ore enrichment - water flow for the year. For the Khoper river, this limit is $1.4 \mathrm{~km} 3$ / year. If we assume that for the enrichment of the annual volume of ore (3-4 million tons) will require about 300 million $\mathrm{m} 3$ of water, the flotation will take $20 \%$ of this flow.

When a shaft is being drilled, groundwater should be pumped out so that it does not reach or flood the ore body.

When water is pumped out, a depression funnel is formed with a center at the bottom of the shaft. Calculations of the depressions funnel radius were performed for two periods. The first one is at the opening of the field, which was taken for two years, and the second, when developing the field itself, conditionally accepted for 10 years (in fact, the development of the field will last 30 years). Estimated calculations of the funnel radius were $11 \mathrm{~km}$ for the opening period and $26 \mathrm{~km}$ for the development period [2].

\section{Soil}

Due to the deposit's development and exploitation, hundreds of hectares of fertile soil and millions of tons of black soil will die. The cost of black soil in nature cannot be estimated at all, but we will try to determine its market value. According to A.S. Kerzhentsev [3], in total, the development of the field will require the alienation of 700 hectares of black soils with the most valuable humus of 385,000 tons, because the meter layer of black earth contains 550 tons / hectare of humus, and 385,000 tons will cost about 4 billion rubles [3].

However, the value of humus $i$ is much higher. The feasibility study of the development of deposits does not take into account the size of the loss of profits from the alienation of valuable soils not for the intended purpose, and it must be calculated for 100 years ahead, although the soil is removed forever.

The removal of the fertile soil layer at the sites of mining and processing of nickel raw materials is perhaps the least of the damage that can be caused to the black soil of the region. The main danger will be represented by dumps of processed rock, with a high content of sulfuric acid salts and elements such as arsenic. Leakage of filtrate from the tailings dump threatens a disaster of the surrounding ecosystem.

\section{Air}

As a result of the output to the surface of a large amount of rock and its storage in the dumps of the plant, particles of rare earth metals will be spread throughout the region and far beyond its borders, which will exceed the maximum permissible concentrations (MPC) in the air by tens and hundreds times. In addition, nickel sulphide compounds, which are the main raw material, will trigger large-scale emissions of sulfur into the atmosphere, which will lead to acid rain.

As a result of the primary enrichment, $60 \%$ of the waste rock containing heavy metals and other harmful substances will be returned to the used mine, and $40 \%$ will remain in the tailing dumps. There is a very high probability of air contamination and polluting the surrounding waters due to dusting from the tailings and infiltration of heavy metals in the soil and through the unsaturated zone into the groundwater.

\section{Economy}

The annual turnover of agricultural products in the Voronezh region exceeds 300 million dollars per year. According to preliminary calculations, production of copper-nickel concentrate will give much less profit. In the long term the development of deposits is unprofitable for Russia, as the value of elite black soil and clean drinking water will constantly increase. On the contrary, nickel prices are falling, they have decreased by 8 times over the past few years. In Russia today there is little need for additional production of nickel. Over the years of reforms, the consumption of nickel by domestic enterprises (metallurgy, electronics, catalysts) fell by 7-10 times. Today, Russian industry uses less than $5 \%$ of the current production. $95 \%$ of nickel produced in the country is exported. According to environmentalists the establishment of effective agricultural sector, is more important the task, and more urgent than the devastation of the subsoil. In the first case, we lay a solid foundation for our future, in the second case, we simply follow the immediate benefit and ignore the negative consequences.

Khoperskiy nature reserve, a home to endangered relict animals' desman, could become the object of eco-tourism and could successfully compete with nickel development of in the region [4]. The development of non-ferrous metals at a densely populated region, even if all environmental requirements are met, will still lead to serious problems. Therefore, European countries prefer to buy non-ferrous metals in third countries than to threaten the safety of their own population.

Production of sulfide copper-nickel ores and their processing in the Voronezh region is unacceptable for the following reasons: In the Voronezh region, there is already a shortage of drinking water that meets the state requirements for its quality. In the process of ore enrichment by flotation requires about fifty cubic meters of water per ton of ore concentrate.

The Kursk magnetic anomaly (KMA), where the radius of the depression funnel reached $80 \mathrm{~km}$ during 80 years of field operation, can be cited as an example of mining and processing plant impact on the environment. The development of non-ferrous metals requires much more water than iron ores development. The prognosis of the underground water depression funnel of in the Khoper region showed that its radius is comparable 
to the KMA, although the development time of the field is 2.5 times less. The basic form of nickel in ores is sulfide, and sulfur released during processing, is easily combined with water, both underground and on the surface, forming acidic compounds that will lead to acid rain.

After carrying out drilling operations in 2014 in the groundwater of the village Elan-Koleno gamma radiation is 150 microx-ray / hour. The water taken from the well for mass spectral analysis, in addition to some indicators exceeding the maximum permissible concentrations (MPC), revealed the content of uranium and thallium exceeding the MPC. Another unexplored issue in the deposit area is seismicity. The seismic stability of the East European platform, including the development area, has not been fully studied. Moreover, the activation of Novokhoperskiy and Troitskoye-Ostrogozhsk tectonic faults was noted: the later is associated with two rocks with high radioactivity-Liskinsky, and Artushevsky in the development region [5].

\section{Conclusion}

Development of copper-nickel deposits in the Voronezh region is extremely complex and costly. We suspect that the comlete project and the normative documentation do not exist today, there are only proposals for the deposit development. There is no widely available information about the proposed waste disposal, data on the composition of industrial effluents in tailing dumps or volumes of waste water in the flotation of raw materials.

\section{References}

1. Ciruelos J, Duchene M (1983) Modele sur micro-ordinateur pour l'analyse de la faisabilite financiere d'un projet minier. Industrie minérale - Les techniques.

2. Zuberec J, Tréger M, Lexa J, Baláž P (2005) Raw material of Slovakia. Štátny geologický ústav Dionýza Štúra, Bratislava, Slovakia.

3. Cehlár M, Maras M (2001) Economic evaluation of Mining Projects, TU, FBERG, Košice.

4. Merciu GL, Merciu FC, Cercleux AL (2016) The assessment of social and economic impacts associated to an abandoned mining site. Case study. Ciudanovita (Romania). International Conference-Environment at a Crossroads: SMART approaches for a sustainable future. Procedia Environmental Sciences 32: 420-430.

5. Rybár P, Cehlár M, Engel J, Mihok J (2005) Evaluation of mineral deposits. ES AMS, FBERG, TU Košice. Slovakia.

6. http://www.geology.sk/new/sites/default/files/media/doc/ rocenky_NS/rocenka_\%20NS_10.pdf.

7. Peter B (2013) Perspective of domestic energetic raw materials using (in Slovak). SGU DŠ, Mineralia Slovaca 45: 225-232.

8. http://www.statistics.sk/pls/elisw/metainfo.explorer

9. Baláž P, Kúšik D (2013) Raw materials of Slovak Republic (in Slovak). Bratislava. Štátny geologický ústav Dionýza Štúra.

10. http://www.hbu.sk/sk/Vyrocna-a-rocna-sprava/Rocne-spravy.alej.

11. http://www.vlada.gov.sk/programove-vyhlasenie-vlady-sr-naroky-2016-2020/. 